\title{
Immune Response and Bone Marker Enzyme Activities of Broiler Birds Fed Graded Level Taurine-Supplemented-Diets
}

\author{
*Ogunbode S. Modupe, Bello R. Adijat and Salau, A. Kayode
}

\author{
Department of chemical Sciences, Biochemistry and Nutrition Unit, College of Natural and Applied Sciences, Fountain University Osogbo. \\ P.M.B. 4491. Osun State, Nigeria.
}

Received $30^{\text {th }}$ December, 2020, Accepted $5^{\text {th }}$ May, 2021

DOI: 10.2478/ast-2021-0003

*Corresponding author

Ogunbode, Simiat Modupe (Ph.D) E-mail: oyewolar@gmail.com

Tel: $+2348038278441 /+2348151219739$

\begin{abstract}
Taurine, a derived amino acid has been proven to play an important biological roles in enhancing bone strength and immune activities of broiler birds. This research investigated the effect of the different concentrations of graded level dietary taurine supplement on immune response of birds against Newcastle Disease Virus (NCDV) and Infectious Bursal Disease Virus (IBDV), as well as on enzymatic markers of bone metabolism and effect on mineral composition. A total of 300 unsexed day-old arbor acre broiler birds were used for this research. The birds were randomly distributed using a completely randomized design into five dietary treatment of six replicates with 10 birds per replicate. Treatment one (T1) served as the control group with $0 \%$ taurine supplement. Treatments 2,3 , 4 , and 5 contained dietary taurine supplements at $0.002,0.004,0.006$, and $0.008 \%$. Antibody titre against NCDV and IBDV were determined according to standard procedures. The study lasted 42 days. Birds on $0.002 \%$ taurine had the highest antibody titre (128.38) against NCDV, while birds on the $0.006 \%$ taurine-supplemented-diet also portrayed a distinct $(\mathrm{p}<0.05)$ titre value $(1029)$ against IBDV. Serum alkaline phosphatase and bone specific alkaline phosphatase $(132.74$ and 150.66$)$ at the $42^{\text {nd }}$ day were highest $(\mathrm{p}<0.05)$ for birds on 0.004 and $0.002 \%$ dietary taurine supplement respectively. The activity of serum tartrate resistant acid phosphatase (44.94) was notably highest $(\mathrm{p}<0.05)$ for birds on $0.008 \%$ taurine. Bone mineral contents showed that birds fed with $0.002 \%$ taurinesupplemented-diet had the highest percentage $(\mathrm{p}<0.05)$ of phosphorous $(9.50)$, calcium $(32.18)$ and phosphate (21.77) composition. Conclusively, inclusion of taurine as dietary supplement has proven useful not only in enhancing the birds' immunity against NCDV an IBDV, but also in boosting bone mineral composition of meat type poultry birds.
\end{abstract}

Keywords: Broiler birds, taurine, bone metabolism, Newcastle disease virus, Infectious Bursal disease virus. 


\subsection{Introduction}

Taurine, a clear and an inodorous free amino acid, is found virtually in all animal tissues (Shim et al., 2006). It is an essential nutrient that plays notable roles in the cells of the body (Schaffer et al., 2010). Dietary taurine supplementation is very essential, mostly because of its' relatively inadequate endogenous synthesis (Kadam and Prabhasankar, 2010). It plays a key role in heart and brain functionality, as well as been a good immunomodulatory and antiinflammatory derived amino acid (Huang et al., 2011).

Malnutrition have a severe effect on broiler birds' immune organs, especially if it occurs at the starter phase (Kirk and Barbul, 1992). Dietary supplementation of laying hens with taurine was able to reduce inflammation, hence assisting poultry birds' immune system (Ma et al., 2017). Infectious bursal disease and Newcastle disease viruses could undermine the immunity of chicks, especially in early days of their life, and could make them vulnerable to other infections (Ma et al., 2017). Taurine, been an immune booster is expected to boost the immunity of broiler birds against viral infections such as Newcastle disease and Infectious bursal disease viruses respectively.

Bone tissues are constantly been metamorphosed by osteoblasts and osteoclasts mainly for bone synthesis and bone resorption simultaneously. Constant bone formation by osteoblasts and bone resorption by osteoclasts helps in maintaining bone mass, and taurine has been proven to enhance bone strength and density of broiler birds (Choi, 2009).

The current research targeted monitoring the effect of graded level taurine supplemented diet on boiler birds' immunity against Newcastle disease and Infectious bursal disease viruses respectively, its effect on the weight of immune organs, as well as on on bone metabolism, density and mineral composition as a measure of bone quality in broiler birds.

\subsection{Experimental}

\section{Source of Taurine}

A $500 \mathrm{~g}$ well packed synthesized taurine supplement with pharmacy number 70403109AA, manufactured by Now food essential products, Schiedam Netherlands, was used for the research.

\section{Experimental Design and Birds Management}

A total of 300 unsexed day-old arbor acre broiler birds purchased from Zartech hatchery farm, Ibadan Oyo State were used for this research. The poultry unit was cleaned, disinfected, electrified and wood shaving were lightly spread in the cages to act as adsorbent of waste, mostly faeces. Facilities for an effective brooding such as thermometer and source of heat were adequately provided for, prior to the arrival of the birds. The birds were then group-brooded for a week, thereafter, they were randomly distributed using a completely randomized design into five dietary treatment of six replicates with 10 birds per replicate. Treatment one (T1) served as the control group with $0 \%$ taurine supplement. Treatments $2,3,4$ and 5 contained dietary taurine supplements at $0.002,0.004,0.006$, and $0.008 \%$ respectively. The birds were initially immunized against Newcastle disease virus (lasota vaccine) on the $8^{\text {th }}$ day when maternal antibody has subsided (Ogunbode et al., 2013). The lasota vaccine was then repeated on the $28^{\text {th }}$ day. The chicks were equally vaccinated against Infectious Bursal Disease (IBDV) virus on day 10 of age via drinking water and then repeated on the $18^{\text {th }}$ day. The experiment ran for six weeks.

\section{Ethical Approval}

All rules and guidelines of ethics involving animal experimentation in research were followed according to laid down rules and regulations. Ethical approval was obtained from the ethical review of the University of Ilorin with the approval number; FERC/ASN/2020/101

\section{Sample Collections for Analysis}

\section{Anti-Newcastle Disease Virus Haemagglutination Assay}

A total of 24 birds were selected per treatment group (n=24) to screen for baseline antibody titre against Newcastle disease virus (NCDV). Non-heparinized blood samples were aseptically collected for haemagglutination assay on the $1^{\text {st }}, 14^{\text {th }}, 28^{\text {th }}$, and $42^{\text {nd }}$ days through the jugular vein of the birds. The blood samples were initially kept at room temperature for 2 hours in test tubes, then centrifuged at 8000 revolution per minute for 10 minutes, and serum pippeted into a welllabelled eppendorf tube for sera storage. Serum prepared from sequential blood collection was heated, inactivated at $56^{\circ} \mathrm{C}$ for 30 minutes and stored at $-20^{\circ} \mathrm{C}$. The level of NCDV antibodies in the serum samples were determined by using haemagglutination inhibition (HI) test as described by Awad et al. (Awad et al., 2015). Antibody level for each serum sample was expressed as Log to the base of two $\left(\log _{2}\right)$ and recorded as the titre value. Published cut-off for selective serum protection level against NCDV (HI to $\log _{2}$ antibody titres $\geq 3.0$ ) as suggested and reported by Allan and Gough, 1974 was adopted for use (Echeonwu et al., 2008).

\section{Serology and Infectious Bursal Disease Virus (IBDV)}

A total of 24 birds were equally selected per treatment group ( $n=24)$ to screen for baseline antibody titre against IBDV. Non-heparinized blood samples were as well aseptically collected via the jugular vein for the determination of antibody titre against IBDV using Enzyme linked immunosorbent assay kit (ELISA) on the $1^{\text {st }}, 14^{\text {th }}, 28^{\text {th }}$, and $42^{\text {nd }}$ day. Serum was separated by centrifugation $(8000$ revolution per minute for 10 minutes) and antibodies specific for IBDV was detected in the sera using an ELISA kit (ProFLOK' Synbiotics Corporation, CA, USA) according to the manufacturer's instructions. One hundred microliters of each sample were used for the assay. Absorbance was measured at $405 \mathrm{~nm}$ using an ELISA reader (SUNRISE Absorbance Reader, TECAN. Option Touchscreen Color - Switzerland) by standard procedures, (Snyder et al., 1984) so as to monitor the effect of the experimental diets on the immune response of the birds.

\section{Measurements of enzymes activities}

Alkaline phosphatase (ALP) activities represents the rate of hydrolysis of 4-nitrophenylphosphate to 4-nitrophenol, described as follows: 


\section{4- Nitrolphenylphosphate $[4-\mathrm{NPP}]+\mathrm{H}_{2} \mathrm{O} \longrightarrow 4$ - Nitrolphenol + Phosphate ion}

The enzyme assay was carried out by method described by Glogowski et al. (2002), but with minor modifications. Five (5) test tube containing $0.45 \mu \mathrm{l}$ dilutions of $4,3.2,2.4,1.6$ and $0.8 \mathrm{mM}$ of 4 Nitrolphenylphosphate [4-NPP] solution was introduced into 5 corresponding test tubes containing $110 \mu \mathrm{l}$ of $0.1 \mathrm{M}$ carbonate buffer. The enzyme reaction was started by adding $10 \mu \mathrm{l}$ of the aliquot of the mixture $(50 \mu \mathrm{l}$ of the serum sample diluted with $50 \mu \mathrm{l}$ of distilled water) into the various test tubes. At a regular interval of $5 \mathrm{~min}$ for 30 $\min , 100 \mu \mathrm{l}$ of $1 \mathrm{M} \mathrm{NaOH}$ was added to the assay mixture to terminate ALP activities. The mixture was transferred into a cuvette and absorbance was measured with a spectrophotometer (SPECTRONIC 20, Labtech- Digital Blood Analyzer (R) at maximum wavelength of $405 \mathrm{~nm}$. The concentration of 4-NP Produced in the various tubes were interpolated from standard curves (Njoku et al., 2011).

Serum bone specific alkaline phosphatase quantification (BALP) is analysed for using the method described by (Jila \& Soleiman, 2012), Activities of Bone specific acid phosphatase (BALP) was determined by adding $200 \mu \mathrm{l}$ of $11 \mathrm{mM}$ phenylalanine to $50 \mu \mathrm{l}$ of the diluted sample to inhibit the activities of other ALP isoforms, then incubated at $37{ }^{\circ} \mathrm{C}$ for 20 minutes. $50 \mu \mathrm{l}$ of $1 \mathrm{M} \mathrm{NaOH}$ was added and absorbance read at $410 \mathrm{~nm}$.

Acid phosphatase (ACP) specific activity was analysed for as described by (Mudasir \& Ashaq, 2016), by adding $50 \mu$ l of distilled water to $50 \mu \mathrm{l}$ of the sample. Sodium acetate $\left(0.1 \mathrm{M}, \mathrm{P}^{\mathrm{H}}=4.5\right)$ was used as buffer. $10 \mu \mathrm{l}$ of $0.1 \mathrm{M}$ magnesium sulphate (MgSO4) was then added and incubated at $37^{\circ} \mathrm{C}$ for 10 minutes, this was followed by addition of $25 \mu \mathrm{l} 10 \mathrm{mM}$ PNPP (Para-nitro phenyl phosphate), incubated at $37^{\circ} \mathrm{C}$ for 30 minutes. Lastly was the addition of $100 \mu \mathrm{l}$ of $1 \mathrm{M} \mathrm{NaOH}$ to each sample mixture to stop the assay reaction and the absorbance was read at $405 \mathrm{~nm}$.

Tartrate resistant acid phosphatase (TRAP) specific activity which represents the rate of conversion of p-NPP to p-nitrophenol by sodium tartrate in TRAP buffer was analysed for by adding about $200 \mu \mathrm{l}$ of distilled water to $50 \mu \mathrm{l}$ of the sample. $100 \mu \mathrm{l}$ of TRAP buffer containing $2.5 \mathrm{mM}$ p-nitrophenyl phosphate (p-NPP), $0.1 \mathrm{M}$ sodium acetate, $0.2 \mathrm{M}$ $\mathrm{KC}, 0.1 \%$ Triton $\mathrm{X}-100,10 \mathrm{mM}$ sodium tartrate, $1 \mathrm{mM}$ ascorbic acid and $100 \mu \mathrm{M} \mathrm{FeCl} 3$ were then added. This was incubated at $37^{\circ} \mathrm{C}$ for 60 minutes. The p- nitrophenol liberated after incubation at $37^{\circ} \mathrm{C}$ for $1 \mathrm{~h}$ was converted into p- nitrophenolate by addition of $50 \mu \mathrm{l}$ of $1 \mathrm{M} \mathrm{NaOH}$ to stop the assay. The absorbance was read at $405 \mathrm{~nm}$. The absorbance of each well was determined using a microplate spectrophotometer at $405 \mathrm{~nm}$. Enzyme activities and specific activities of the enzyme was calculated (Jae-won et al., 2009).

A total of eight birds per treatment were sacrificed by severing the jugular vein for bone quality determination. The birds were sacrificed by severing the jugular vein, the tibia and femur of the birds were carefully removed and manually de-fleshed. Thereafter, the fresh bones were weighed to obtain fresh weights of bones. The lengths of the tibia and femur bones were measured and bone density was calculated $=\frac{\text { Bone } \text { weight }}{\text { Bone length }}$ (Almeida and Bruno, 2006).

Bone digestion was analysed for according to the method of Siemowit et al. (2018). The tibia bone was ashed and mineralized in a muffle furnace at $750{ }^{\circ} \mathrm{C}$ and left for $24 \mathrm{hrs}$ until a white ashed colour was gotten (Siemowit et al., 2018). About 2g of the ashed sample was weighed into $100 \mathrm{ml}$ digestion flask and immediately $30 \mathrm{ml}$ of Triple acid (i.e. nitric, sulphuric, perchloric acid at a ratio of 650:70:20 ml) were added. The flask and its contents were transferred into a hot digestion block for $1 \mathrm{hr}$. The digestion was completed when the white thick fumes of the perchloric acid cease to appear and the volume of the digest eventually reduced to $5 \mathrm{ml}$. The digest was allowed to cool for 30 mins by adding some amount of distilled water after which it was transferred into a $50 \mathrm{ml}$ plastic bottle and then diluted to $50 \mathrm{ml}$. This serves as the digestion volume. Homogeneous mixture was subsequently obtained by shaking the bottle.

The concentrations of calcium and magnesium in the bone were determined using Atomic Absorption Spectrophotometer (AAS) method of analysis according to the method described by Skoog et al. (2006). An air-acetylene flame for Ca analysis, and a nitrous oxideacetylene flame for $\mathrm{Mg}$ analysis were used. Different standard solutions were produced from pure stock solutions containing 1,000 ppm of the elements (Merck 1.09943 Titrisol, Merck 1.09949 Titrisol, and Merck 1.09953 Titrisol for Ca and Mg, Merck KGaA, Darmstad, Germany). In the Ca analysis, a strontium chloride solution $(50 \mathrm{~g} / \mathrm{L}$; Merck 1.07865, Merck KGaA) was used as a releasing agent (Palma et al., 2015).

Actual concentration $=$

$$
\frac{\text { AAS Reading } \times \text { Digestion volume } \times \text { Dilution Factor }}{\text { weight of the sample. }}
$$

Concentration in part per million (ppm) or $\mathrm{mg} / \mathrm{kg}$ was expressed in percentage by dividing by ten thousand to get the percentage elemental calcium and magnesium in the bone.

Total phosphorus content of the samples was determined by colorimetric method using vanadomolybdate method of phosphorus determination. Briefly described, Ammonium molybdate reacts under acid conditions to form heropoly acid, molybdate reacts under acid conditions to form molybdo phosphoric acid. In the presence of vanadium, yellow vanadomybdo phosphoric acid is formed. The intensity of the yellow colour is proportional to phosphate concentration.

Procedure: To about $0.5 \mathrm{ml}$ of the pipetted sample, $4 \mathrm{ml}$ of Vanadatemolybdate reagent $(25 \mathrm{~g}$ ammonium molybdate $+1.25 \mathrm{~g} \mathrm{NH}$ metavanadate $+330 \mathrm{ml} \mathrm{HNO}_{3}+300 \mathrm{ml}$ distilled water) was added as the colour developing reagent. The colour was allowed to develop for $30 \mathrm{~min}$. The optical density of the sample was determined and the result was computed in part per million and expressed in percentage by dividing by ten thousand (Palma et al., 2015).

Phosphorus $(\mathrm{ppm}$ or $\mathrm{mg} / \mathrm{kg})=$

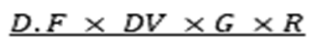

Wt 
Elemental phosphorus (\% P) Phosphorus (mg/kg)

10,000

Dilution factor (D.F) $=\frac{\text { Final sample developed }}{\text { Volume of aliquot used }}$

Dilution volume (DV) $=$ Final sample developed + aliquot used $\mathrm{DV}=30$

Where $\mathrm{G}=$ Constant value (90.91) $\mathrm{s}$

$\mathrm{R}=$ Reading (Absorbance) from colorimeter

$\mathrm{Wt}=$ Weight of the sample used.

\section{Statistical analysis}

Data for all analysis (alkaline phosphatase, bone specific alkaline phosphatase quantification, acid phosphatase, tartrate resistant acid phosphatase, bone quality determination and bone mineral composition) were presented as means \pm standard error of the mean (SEM). Continuous variables were tested for normality and then analysed using one-way ANOVA procedure of SAS. Significant difference between treatment means were separated using Duncan's Multiple Range Test (SAS, 2000). $\mathrm{p}<0.05$ was considered as significant.

\subsection{Results}

\section{Experimental feed}

Table 1 shows the gross composition $(\mathrm{kg} / 100 \mathrm{~g})$ of the experimental diets. The only ingredients (added over) that was varied was taurine, which was the main target of the research. The diet were adequately compounded to meet up with the basic energy and protein requirement, as well as the basic mineral compositions of the birds.

Calculated crude protein content of the diet ranging between 18.05 and $22.57 \%$ is within the range recommended by NRC 1994 . The crude fibre ( 4.38 to $5.40 \%$ ), ether extract ( 4.4 to $5.10 \%$ ) and ash (3.74) were all also within the NRC recommended ranges. The analysed proximate composition in Table $2 \mathrm{~b}$ commensurate the calculated nutrient composition in table $2 \mathrm{a}$.

\section{Immunonutrition}

Heamagglutination inhibition titre (HI - $\log _{2}$ ) against NCDV (Table 3) showed that the geometric mean titre, or simply put, antibody titre taken as basal titre value on day 1 were uniform ( $p>0.05$ ). On day 14, birds on $0.002 \%$ taurine-supplemented diet had a distinct $(\mathrm{p}<0.05)$ antibody titre value. The titre value for birds on the control diets and those on $0.006 \%$ taurine supplements were not totally different from the titre value of birds on $0.004 \%$ supplement against NCDV. Birds on $0.008 \%$ dietary supplement had the least antibody titre value against NCDV on day 14. The pattern of the performance for titre values on the $28^{\text {th }}$ day followed suit exactly with what was obtained on the $14^{\text {th }}$ day, with birds on $0.002 \%$ taurine having the highest antibody titre against NCDV. Also on the $42^{\text {nd }}$ day, birds on the $0.002 \%$ supplementary diets had the highest titre value against NCDV. The titre value of birds on the control diet did not differ ( $p>0.05$ ) from those of the birds on $0.004 \%$ supplementary diet. In the same vein, no noticeable differences (in the titre value of birds on $0.006 \%$ and $0.008 \%$ against NCDV. Overall, the antibody titre value increases as the birds ages.
Antibody titre against IBDV (Table 4) showed a progressive improvement in the titre values of the birds as they aged. The birds had similar basal titre value ( $p>0.05)$ at day old. At the $14^{\text {th }}$ day, birds placed on $0.008 \%$ dietary taurine supplement had the best titre value ( $p>0.05$ ) against IBDV. At the $28^{\text {th }}$ day, birds placed on $0.006 \%$ dietary supplement had a distinct titre value $(\mathrm{p}<0.05)$ against IBDV. This followed suit with what was obtained on the $42^{\text {nd }}$ day, birds on the $0.006 \%$ taurine-supplemented-diet also portrayed a distinct $(\mathrm{p}<0.05)$ titre value, followed by the titre value of the birds on $0.004 \%$ taurinesupplemented-diet. Throughout the experimental period, with the exception of the basal titre value, birds placed on $0 \%$ dietary supplement had the least titre value against IBDV.

The result of the liver and the immune organs to body weight ratio (Table 5) revealed that there were no differences ( $p>0.05)$ among the liver to body weight ratio of birds on diet 2 , diet 3 , and diet $4(0.002 \%$, $0.004 \%$, and $0.006 \%$ ) taurine-supplemented-diets, respectively when compared with those of the birds on diet $10 \%$ taurine-supplementeddiets). Birds on diet 5 (0.008\% taurine-supplemented-diets) had a significant $(\mathrm{p}<0.05)$ liver weight to body weight ratio when compared with those of the birds in diet 1 ( $0 \%$ taurine-supplemented-diets). The spleen to body weight ratio of birds on diet 3 and 4 (0.004 and 0.006) $\%$ taurine-supplemented-diets were not so much different, but noticeably different $(\mathrm{p}<0.05)$ from the spleen to body weight ratio of the birds on $0 \%$ taurine-supplemented-diets. Birds on diet $5(0.008 \%)$ taurine-supplemented-diets had a significant spleen to body weight ratio when compared with those of the birds on the control diets $(0 \%$ taurine-supplemented-diets). The bursal of fabricius weight to body weight ratio for birds 0.002 and $0.004 \%$ taurine-supplemented diets were slightly different from the weight of same organ for birds on $0 \%$ and $0.006 \%$ taurine-supplemented diets and glaringly $(\mathrm{p}<0.05)$ different from the weight of the organ for birds on $0.008 \%$ of experimental diet.

\section{Dietary Taurine and effect on bone marker enzymes}

Serum bone formation markers (Table 6) revealed an initial surge in the activities of the enzymes $(\mathrm{p}<0.05)$ in the serum of the birds on the different taurine-supplemented-diets when compared with that of the control within the first few weeks of life, then later decreased as the birds ages. Specifically, the serum alkaline phosphatase and bone specific alkaline phosphatase at the $42^{\text {nd }}$ day were highest $(\mathrm{p}<0.05)$ for birds on diet 2,3 , and $4(0.002,0.004$, and $0.006 \%)$ dietary taurine supplement and lowest $(\mathrm{p}>0.005)$ for birds on diet 1 and $5(0$ and $0.008 \%)$.

Serum bone resorption marker (Table 7) revealed a relatively stable serum acid phosphatase concentration, though at the end of the feeding trial, birds on $0.008 \%$ taurine-supplemented diet had the highest $(\mathrm{p}<0.05)$ activities of the enzyme, and the least concentration was found in birds on the control $(0 \%)$ diet. The concentration of the serum tartrate resistant acid phosphatase increased relatively as the birds ages, at the end of the feeding trial, the activity of the enzyme was notably highest $(\mathrm{p}<0.005)$ for birds on $0.008 \%$ taurine and least also for birds on the control diet. 
The bone density (tibia and femur bone morphometry) of the birds is as shown in (Table 8). The tibia bone weight of the birds on $0.002 \%$ and $0.008 \%$ dietary supplement were the densest $(p<0.05)$. This is followed by the tibia bone weight of birds placed on $0.004 \%$ and $0.006 \%$ dietary supplement. Birds on the control diet $(0 \%$ taurinesupplemented diet) had the least tibia bone weight. There were no striking differences ( $p>0.05)$ amongst the length of the tibia bone with respect to the dietary taurine treatment inclusion in birds' feeds, but numerically, birds on $0.006 \%$ dietary-taurine-supplement had the longest tibia bone length. On the other hand, birds on $0.002 \%$ and $0.004 \%$ taurine supplement had the densest $(\mathrm{p}<0.05)$ femur bone weight. This is followed by the femur bone weight of birds placed on $0.006 \%$ and $0.008 \%$ dietary-taurine-supplement. In the same vein, birds on the control diet had the least femur bone weight. The femur bone length also showed no marked difference ( $p>0.05)$, but numerically, birds placed on $0.006 \%$ taurine-supplemented-diet also had the longest femur bone length. The bone density is a ratio of bone weight to length, hence followed the same pattern just as tibia and femur bone morphometry report.

Bone mineral contents (Table 9) showed that birds fed with $0.002 \%$ taurine-supplemented-diet had the highest percentage $(\mathrm{p}<0.05)$ of phosphorous, calcium and phosphate composition, birds on $0 \%$, $0.004 \%$ and $0.006 \%$ dietary supplements had the highest magnesium composition $(\mathrm{p}<0.05)$. Birds on $0.008 \%$ dietary supplement also contained a higher percentage $(\mathrm{p}<0.05)$ of calcium composition. Birds on the control diet had the least amount of phosphorus and phosphate composition. The calcium composition of birds on $0.006 \%$ taurine is similar ( $p>0.05)$ to that of the birds on the control diet.
Table 1: Gross composition (kg/100g) of experimental diets

\begin{tabular}{cccc}
\hline & \multicolumn{2}{c}{ Experimental phase } & \\
Ingredient $(\mathrm{kg})$ & Pre-starter & Starter & Finisher \\
\hline $\begin{array}{c}\text { Taurine supplement } \\
\text { (\%) }\end{array}$ & & $0.002-0.008$ \\
Maize & 44.60 & 51.38 & 56.00 \\
Oil & 0.30 & 0.40 & 2.00 \\
Soybeans meal & 32.30 & 21.29 & 18.00 \\
Water & 10.80 & 11.00 & 9.00 \\
Groundnut cake & 9.00 & 13.00 & 2.00 \\
Lime stone & 1.90 & 1.55 & 11.22 \\
Dicalcium & 0.33 & 0.41 & 2.00 \\
phosphate & & & \\
Common salt & 0.38 & 0.35 & 0.4 \\
Methionine & 0.14 & 0.17 & 0.37 \\
Lysine & 0.00 & 0.20 & 0.62 \\
Premix & 0.25 & 0.25 & 0.14 \\
Total & 100 & 100 & 100 \\
\hline
\end{tabular}

Table 2: Calculated Nutrient Composition (\%) and Proximate Analysis (g/100 g DM) of Experimental diets.

\begin{tabular}{llll}
\hline Ingredients & Pre-starter & Starter & Finisher \\
\hline Crude protein (C) & 22.57 & 20.12 & 18.05 \\
Crude Protein (P) & 22.97 & 20.34 & 18.38 \\
Crude fibre (C) & 5.40 & 4.85 & 4.38 \\
Crude fibre (P) & 5.33 & 4.93 & 4.52 \\
Ether extract (C) & 5.10 & 4.84 & 4.40 \\
Ether extract (P) & 4.99 & 4.72 & 4.21 \\
Ash (C) & 3.74 & 3.74 & 3.74 \\
Ash (P) & 3.82 & 3.72 & 3.93 \\
\hline
\end{tabular}

$\mathrm{C}=$ calculated and $\mathrm{P}=$ proximate

Table 3: Heamagglutination inhibition titre (HI - Log2) against Newcastle Disease Virus (NCDV) of broiler birds fed graded level taurinesupplemented-diets.

\begin{tabular}{|c|c|c|c|c|c|c|c|c|}
\hline \multirow[b]{2}{*}{ DIETS } & \multicolumn{2}{|c|}{ DAY 1} & \multicolumn{2}{|c|}{ DAY 14} & \multicolumn{2}{|c|}{ DAY 28} & \multicolumn{2}{|c|}{ DAY 42} \\
\hline & $\begin{array}{l}\text { Geometric } \\
\text { mean titre }\end{array}$ & $\begin{array}{l}\text { Antibody } \\
\text { titre }\end{array}$ & $\begin{array}{l}\text { Geometric } \\
\text { mean titre }\end{array}$ & $\begin{array}{l}\text { Antibody } \\
\text { titre }\end{array}$ & $\begin{array}{l}\text { Geometric } \\
\text { mean titre }\end{array}$ & $\begin{array}{l}\text { Antibody } \\
\text { titre }\end{array}$ & $\begin{array}{l}\text { Geometric } \\
\text { mean titre }\end{array}$ & $\begin{array}{l}\text { Antibody } \\
\text { titre }\end{array}$ \\
\hline DIET 1 & $1.87^{a}$ & $2^{1}$ & $8.00^{\mathrm{ab}}$ & $2^{3}$ & $8.42^{\mathrm{ab}}$ & $2^{3}$ & $64.50^{\mathrm{b}}$ & $2^{6}$ \\
\hline DIET 2 & $1.75^{\mathrm{a}}$ & $2^{1}$ & $8.38^{a}$ & $2^{3}$ & $16.13^{a}$ & $2^{4}$ & $128.38^{a}$ & $2^{7}$ \\
\hline DIET 3 & $1.63^{\mathrm{a}}$ & $2^{1}$ & $4.37^{b}$ & $2^{2}$ & $8.25^{b}$ & $2^{3}$ & $64.75^{b}$ & $2^{6}$ \\
\hline DIET 4 & $1.75^{\mathrm{a}}$ & $2^{1}$ & $8.13^{\mathrm{ab}}$ & $2^{3}$ & $8.88^{\mathrm{ab}}$ & $2^{3}$ & $32.75^{c}$ & $2^{5}$ \\
\hline DIET 5 & $1.75^{\mathrm{a}}$ & $2^{1}$ & $4.00^{\mathrm{b}}$ & $2^{2}$ & $8.00^{\mathrm{b}}$ & $2^{3}$ & $32.75^{c}$ & $2^{5}$ \\
\hline SEM & 0.12 & & 0.68 & & 2.12 & & 4.67 & \\
\hline
\end{tabular}


Table 4: Antibody Titre against Infectious Bursal Disease Virus (IBDV) of broiler birds fed graded level taurine-supplemented-diets.

\begin{tabular}{lllll}
\hline DIETS & $1^{\text {st }}$ Day & $14^{\text {th }}$ Day & $28^{\text {th }}$ day & $42^{\text {nd }} d a y$ \\
\hline DIET 1 & $10.11 \pm 1.430^{\mathrm{a}}$ & $16.88 \pm 2.295^{\mathrm{e}}$ & $85.00 \pm 5.720^{\mathrm{e}}$ & $143.00 . \pm 6.380^{\mathrm{e}}$ \\
DIET 2 & $10.25 \pm 1.330^{\mathrm{a}}$ & $49.00 \pm 8.952^{\mathrm{d}}$ & $134.75 \pm 12.719^{\mathrm{d}}$ & $210.00 \pm 7.834^{\mathrm{d}}$ \\
DIET 3 & $9.99 \pm 1.440^{\mathrm{a}}$ & $134.38 \pm 6.657^{\mathrm{c}}$ & $508.75 \pm 26.090^{\mathrm{b}}$ & $885.00 \pm 9.342^{\mathrm{b}}$ \\
DIET 4 & $10.31 \pm 1.330^{\mathrm{a}}$ & $209.62 \pm 22.071^{\mathrm{b}}$ & $669.12 \pm 71.620^{\mathrm{a}}$ & $1029.00 \pm 5.432^{\mathrm{a}}$ \\
DIET 5 & $10.02 \pm 1.340^{\mathrm{a}}$ & $283.62 \pm 10.680^{\mathrm{a}}$ & $372.00 \pm 2.847^{\mathrm{c}}$ & $532.00 \pm 4.796^{\mathrm{c}}$
\end{tabular}

Mean \pm SEM (Standard Error of Mean). Diet 1 - 0\%, Diet 2 - 0.002\%, Diet 3 - 0.004\%, Diet 4 - 0.006\%, Diet 5 - 0.008\% taurine-supplemented-diets respectively. abcde are means within same column with different superscripts that are significantly different $(\mathrm{p}<0.05)$.

Table 5: Liver and immune organs to body weight ratio of broiler birds fed graded level taurine-supplemented-diets.

\begin{tabular}{ccccccc}
\hline Parameter(g) & DIET 1 & DIET 2 & DIET 3 & DIET 4 & DIET 5 & SEM \\
\hline Liver & $1.86^{\mathrm{b}}$ & $1.80^{\mathrm{b}}$ & $1.90^{\mathrm{b}}$ & $1.94^{\mathrm{b}}$ & $2.13^{\mathrm{a}}$ & 0.07 \\
Spleen & $0.09^{\mathrm{c}}$ & $0.11^{\mathrm{b}}$ & $0.12^{\mathrm{ab}}$ & $0.12^{\mathrm{ab}}$ & $0.14^{\mathrm{a}}$ & 0.04 \\
Bursa of fabricius & $0.07^{\mathrm{ab}}$ & $0.04^{\mathrm{b}}$ & $0.03^{\mathrm{b}}$ & $0.06^{\mathrm{ab}}$ & $0.19^{\mathrm{a}}$ & 0.04 \\
\hline
\end{tabular}

Diet 1 - 0\%, Diet 2 - 0.002\%, Diet 3 - 0.004\%, Diet 4 - 0.006\%, Diet 5 - 0.008\% taurine-supplemented-diets respectively. SEM: Standard Error of Mean. abc are means within same column with different superscripts that are significantly different $(\mathrm{p}<0.05)$.

Table 6: Serum bone formation marker of broiler birds fed graded level taurine- supplemented-diets.

Alkaline phosphatase (mM/min/mg-protein) Bone specific alkaline phosphatase (mM/min/mg-protein)

\begin{tabular}{|c|c|c|c|c|c|c|c|c|}
\hline \multirow[b]{2}{*}{ DIETS } & \multicolumn{4}{|c|}{ 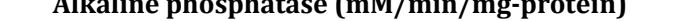 } & \multicolumn{4}{|c|}{ 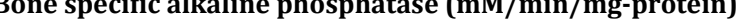 } \\
\hline & $1^{\text {ST }}$ DAY & $14^{\mathrm{TH}}$ DAY & $2^{\text {TH }}$ DAY & 42 ND DAY & $1^{\text {ST }}$ DAY & $14^{\mathrm{TH}}$ DAY & $28^{\mathrm{TH}}$ DAY & 42 ND DAY \\
\hline DIET 1 & $3.25^{\mathrm{d}}$ & $171.83^{\mathrm{a}}$ & $70.35^{c}$ & $35.19^{d}$ & $3.92^{\mathrm{d}}$ & $181.75^{b}$ & $130.80^{c}$ & $119.50^{\mathrm{c}}$ \\
\hline DIET 2 & $5.45^{\mathrm{b}}$ & $140.50^{c}$ & $103.39 \mathrm{~b}$ & $102.79^{b}$ & $6.06^{\mathrm{b}}$ & $167.26^{c}$ & $162.61^{\mathrm{b}}$ & $150.66^{a}$ \\
\hline DIET 3 & $4.98^{\mathrm{bc}}$ & $161.56^{\mathrm{ab}}$ & $111.36^{\mathrm{a}}$ & $132.74^{\mathrm{a}}$ & $5.21^{\mathrm{c}}$ & $177.21^{b c}$ & $159.76^{b}$ & 133. $27^{b}$ \\
\hline DIET 4 & $3.75^{c}$ & $150.00^{\mathrm{b}}$ & $106.62^{\mathrm{ab}}$ & $116.90^{\mathrm{ab}}$ & $7.30^{\mathrm{ab}}$ & $200.85^{a}$ & $162.04^{\mathrm{b}}$ & $130.74^{b}$ \\
\hline DIET 5 & $7.96^{\mathrm{a}}$ & $112.41^{\mathrm{d}}$ & $66.11^{\mathrm{c}}$ & $52.40^{c}$ & $9.31^{\mathrm{a}}$ & $199.04^{\mathrm{ab}}$ & $204.18^{a}$ & $121.37^{c}$ \\
\hline SEM & 0.50 & 0.54 & 4.76 & 6.17 & 0.40 & 3.84 & 3.74 & 2.66 \\
\hline
\end{tabular}

Diet 1 - 0\%, Diet 2 - 0.002\%, Diet 3 - 0.004\%, Diet 4 - 0.006\%, Diet 5 - 0.008\% taurine-supplemented-diets respectively. SEM: Standard Error of Mean. abcd are means within same column with different superscripts that are significantly different $(\mathrm{p}<0.05)$.

Table 7: Serum bone resorption marker of broiler birds fed graded level taurine supplemented diets. Acid phosphatase (mM / min /mg protein) Tartrate resistant acid phosphatase $(\mathrm{mM} / \mathrm{min} / \mathrm{mg}$ protein)

\begin{tabular}{|c|c|c|c|c|c|c|c|c|}
\hline \multirow{2}{*}{ DIETS } & & & & & \\
\hline & $1^{\mathrm{ST}} \mathrm{DAY}$ & $14^{\mathrm{TH}} \mathrm{DAY}$ & $\mathbf{2 8}^{\text {TH }}$ DAY & $42^{\mathrm{ND}} \mathrm{DAY}$ & $1^{\text {ST }}$ DAY & $14^{\mathrm{TH}}$ DAY & $28^{\mathrm{TH}}$ DAY & $42^{\mathrm{ND}} \mathrm{DAY}$ \\
\hline DIET 1 & $9.05^{a}$ & $8.96^{a}$ & $3.83^{\mathrm{d}}$ & $5.04^{\mathrm{d}}$ & $10.38^{\mathrm{ab}}$ & $21.67^{c}$ & $17.39^{\mathrm{bc}}$ & $28.61^{c}$ \\
\hline DIET 2 & $7.32^{\mathrm{b}}$ & $8.88^{a}$ & $5.37^{c}$ & $6.11^{\mathrm{c}}$ & $11.06^{\mathrm{a}}$ & $13.33^{\mathrm{d}}$ & $19.94^{b}$ & $31.65^{b c}$ \\
\hline DIET 3 & $7.03^{\mathrm{b}}$ & $6.97^{b}$ & $5.81^{b c}$ & $5.03^{d}$ & $10.07^{\mathrm{ab}}$ & $26.99^{b}$ & $15.97^{c}$ & $34.04^{\mathrm{b}}$ \\
\hline DIET 4 & $5.30^{c}$ & $5.98^{b}$ & $7.23^{\mathrm{b}}$ & $9.21^{\mathrm{a}}$ & $8.83^{\mathrm{b}}$ & $23.71^{\mathrm{bc}}$ & $16.35^{c}$ & $35.78^{\mathrm{ab}}$ \\
\hline DIET 5 & $2.72^{\mathrm{d}}$ & $5.69^{b}$ & $7.68^{\mathrm{a}}$ & $9.08^{b}$ & $7.30^{c}$ & $30.80^{\mathrm{a}}$ & $20.50^{\mathrm{a}}$ & $44.94^{\mathrm{a}}$ \\
\hline SEM & 0.50 & 0.49 & 0.49 & 0.68 & 0.60 & 1.53 & 1.00 & 2.26 \\
\hline
\end{tabular}

Diet 1 - 0\%, Diet 2 - 0.002\%, Diet 3 - 0.004\%, Diet 4 - 0.006\%, Diet 5 - 0.008\% taurine-supplemented-diets respectively. SEM: Standard Error of Mean. abcd are means within same column with different superscripts that are significantly different $(p<0.05)$.

Table 8: Bone density of broiler birds fed graded level taurine-supplemented-diets

\begin{tabular}{|c|c|c|c|c|c|c|}
\hline \multirow[b]{2}{*}{ DIETS } & \multicolumn{3}{|c|}{ Tibia Bone Morphometry } & \multicolumn{3}{|c|}{ Femur-Bone Morphometry } \\
\hline & Weight (g) & Length(cm) & Density (g/cm) & Weight (g) & Length(cm) & Density $(\mathrm{g} / \mathrm{cm})$ \\
\hline DIET 1 & $11.62^{\mathrm{b}}$ & $7.04^{\mathrm{a}}$ & $1.64^{\mathrm{b}}$ & $13.25^{c}$ & $6.90^{\mathrm{a}}$ & $1.93^{\mathrm{c}}$ \\
\hline DIET 2 & $14.25^{\mathrm{a}}$ & $7.03^{\mathrm{a}}$ & $1.79^{a}$ & $17.38^{\mathrm{a}}$ & $6.92^{\mathrm{a}}$ & $2.50^{\mathrm{a}}$ \\
\hline DIET 3 & $13.13^{\mathrm{ab}}$ & $7.25^{\mathrm{a}}$ & $1.84^{\mathrm{a}}$ & $17.00^{\mathrm{a}}$ & $7.25^{\mathrm{a}}$ & $2.36^{\mathrm{a}}$ \\
\hline DIET 4 & $12.63^{\mathrm{ab}}$ & $7.44^{\mathrm{a}}$ & $1.70^{\mathrm{ab}}$ & $15.00^{\mathrm{ab}}$ & $7.43^{a}$ & $2.04^{\mathrm{ab}}$ \\
\hline DIET 5 & $14.00^{\mathrm{a}}$ & $6.93^{\mathrm{a}}$ & $2.04^{\mathrm{a}}$ & $13.88^{\mathrm{b}}$ & $6.98^{\mathrm{a}}$ & $1.98^{\mathrm{b}}$ \\
\hline SEM & 1.34 & 0.25 & 0.18 & 1.40 & 0.20 & 0.17 \\
\hline
\end{tabular}

Diet 1 - 0\%, Diet 2 - 0.002\%, Diet 3 - 0.004\%, Diet 4 - 0.006\%, Diet 5 - 0.008\% taurine-supplemented-diets respectively. SEM: Standard Error of Mean. abc are means within same column with different superscripts that are significantly different $(\mathbf{p}<0.05)$.

21|Annals of Science and Technology 2021 Vol. 6(1) 16-25 This journal is (C) The Nigerian Young Academy 2021 
Table 9: Bone-chemical-composition of broiler birds fed graded level taurine-supplemented-diets

\begin{tabular}{|c|c|c|c|c|c|c|}
\hline Parameters (\%) & DIET 1 & DIETS 2 & DIETS 3 & DIETS 4 & DIETS 5 & SEM \\
\hline Calcium & $27.630^{\mathrm{b}}$ & $32.180^{\mathrm{a}}$ & $23.930^{c}$ & $28.140^{\mathrm{b}}$ & $35.400^{\mathrm{a}}$ & 1.340 \\
\hline Magnesium & $0.027^{a}$ & $0.016^{\mathrm{b}}$ & $0.029 \mathrm{a}$ & $0.026^{\mathrm{a}}$ & $0.024 \mathrm{ab}$ & 0.003 \\
\hline Phosphate & $18.310^{c}$ & $21.770^{\mathrm{a}}$ & $20.630^{\mathrm{ab}}$ & $19.250^{\mathrm{bc}}$ & $20.150^{b}$ & 0.460 \\
\hline
\end{tabular}

Diet 1 - 0\%, Diet 2 - 0.002\%, Diet 3 - 0.004\%, Diet 4 - 0.006\%, Diet 5 - 0.008\% taurine-supplemented-diets respectively. SEM: Standard Error of Mean. abc are means within same row with different superscripts that are significantly different $(p<0.05)$.

\subsection{Discussion}

Infectious bursal disease and Newcastle disease viruses (IBDV AND NCDV) are broiler birds' viral infections that are capable of grossly affecting birds' health, production and income of poultry farmers if not well handled. The efficacy of taurine as an immunological agent against common diseases in broiler birds were experimented against the two diseases, and were found to be effective as it boosts and generally improve the antibody titre against the diseases as the birds ages. Dietary betaine (Bet) supplementation of heat stressed broiler birds' diet have been proven by Rao et al. (Rao et al., 2011) to increase primary antibody titre of birds against IBDV and NCDV. Kettunen et al. (Kettunen et al., 2001) and Klasing et al. (Klasing et al., 1991) reported that dietary Bet supplementation $(1 \mathrm{~g} / \mathrm{kg}$ ) enhanced broiler birds' humoral immunity. Hassan et al. (Hassan et al., 2011) also concluded that dietary supplementation of broiler birds with Bet enhanced the antibody titers against sheep red blood cell in heat stressed New Zealand White rabbits. Tsiagbe et al. (Tsiagbe et al., 1987) on the other hand noticed that supplementation of broiler birds' feed with Bet $(0.121 \%$ of the diet) did not have any noticeable effect on the humoral immunity of broilers at six weeks posthatch.

The bursa of Fabricius is an important lymphoid organ, its' presence is germane to the development and maturation of B-lymphocytes (Li et al., 2005; Wang, 2009). Schuller-Levis et al. (Schuller-Levis et al., 1990) and Wang et al. (2014) both reported that taurine supplementation at various levels usually enhance the weight of immune organs like spleen, thymus and bursal of fabricius. The favourable effect of taurine on the development and growth of the immune organs especially at $0.008 \%$ supplementation level can be a good signal to its' ability at enhancing the overall immune functions.

Serum bone specific alkaline phosphatase is very specific for bone formation. The enzyme is secreted by osteoblasts for biological deposition of or conversion into calcium carbonate or some other insoluble calcium compounds (Osyczka and Leboy, 2005). Structural composition of bone mostly is a function of the genetic make-up of the birds in term of strain or could equally be linked to the quality of feed. Modern broiler breeds targeting maximal meat production do have various skeletal deformities like abnormal cartilage development in the proximal end of the tibia, excessive inward and outward angulation of the distal segment of a bone or joint and other related crisis, mostly because they reach table size as early as five to eight weeks (Ammann et al., 2000). Research has shown that amino acids generally are capable of improving the structure and quality of bone formation (Ammann et al., 2000). Notable amount of taurine is moved into bone tissues, and has been proven to aid bone anabolic effect by halting bone resorption. It equally plays a stimulatory role on the activity of alkaline phosphatase and the formation of collagen (Koide et al., 1999; Park et al., 2001; Yasutomi et al., 2002). Alkaline phosphatase is a wide spread quaternary enzyme attached to glycosylphosphatidylinositol moieties found situated at the external surface of a cell membrane (Park et al., 2001). More activities of the enzymes in the serum in this case could indicate poor bone formation, while lesser amount in the serum could indicate better bone formation. Lesser amount of the serum enzymes activities in birds fed with $0.008 \%$ taurine-based diet is an indication of the ability of taurine at this concentration in preventing against bone loss, hence halting bone resorption and encouraging bone osteoblasts metabolism through stimulation of extracellular signal regulated protein kinase phosphorylation (Park et al., 2001; Ahmed and Hamza, 2009).

Serum tartrate resistant-acid phosphatase is closely related to bone resorption. It is the only enzyme secreted by osteoclasts (Nordin, 1978; Kleerekoper et al., 1994; Kirstein et al., 2006). Significant increased amount of serum bone formation and bone resorption markers of birds at $0.006 \%$ supplementation level is an indication of effective reformation and dissolution of bone which requires asynchronous action of bone-forming cells (osteoblasts) and boneresorbing cells (osteoclasts) occurring together simultaneously during the process of bone metabolism (remodelling) so as to maintain skeletal homeostasis by acting as reservoir for minerals and guiding against excessive bone loss (Hazarina,. 2017).

Taurine has been proven to impact bone mineral density and bone mineral content (Lubec et al., 1997; Koide et al., 1999). The marked improvement in the tibia cum femur weight and length (bone density) of birds on the experimental diets (0.002 to $0.008 \%$ ) negate the findings of Choi and Seo, 2013 which reported that taurine had no effect on the femur bone mineral density in experimental male rats. The authors emphasised that the femur bone mineral density per weight (FBMD/wt) were not significantly different between experimental groups, control group inclusive.

Enhanced bioavailability of trace elements/minerals usually assist the morphology of bone cartilages (Bao et al., 2009; Sharideh et al., 2015). Phosphorus is very important for a number of cellular activities used to maintain homeostasis in animals such as the formation of nucleic acids, bioactive signaling proteins, phosphorylating enzymes, and a naturally occurring mineral form of calcium apatite (hydroxyapatite) 
(Berndt et al., 2005). Calcium is used in many vital cellular functions as well including mediating nerve transmission, muscle function, intracellular signaling, secretion of vital chemical substances, and widening of blood vessel. Both minerals are usually monitored through their concentrations in the blood and the surrounding tissue. Free calcium in the blood is majorly used for bone formation in growing broilers (Tucker et al., 2007). The marked improvement in the bone mineral composition of birds on the various concentration of taurine supplemented diet is in accordance with the findings of Choi and Seo, 2013; Choi and DiMarco 2009 which reported a higher femur bone mineral contents per weight (FBMC/wt) of the rats fed taurinesupplemented diet than in those rats fed with the control diet. The improvement in bone mineral content has been proven to reduce osteoporosis, atherosclerosis and inflammation in experimental animal models (Belury, 2002). This unique feature has given taurine an edge at addressing and managing various chronic diseases (Hayes and Stuiman, 1981).

\section{Conclusion}

Inclusion of taurine as dietary supplement within the range of 0.002 to $0.008 \%$ has proven useful not only in enhancing the birds' immunity against NCDV and IBDV, but also in maintaining bone strength of meat type poultry birds that are always encountered with bone malformation as result of the meat to bone ratio proportion. Taurine has also been found useful in maintaining a good phosphorous to calcium ratio in broiler birds, another strong determinant of bone strength.

\section{Acknowledgements}

The authors acknowledged the contribution of the following; Fountain University Osogbo laboratory staff, Late Dr Ajiboye's laboratory staff at Ilorin, Mr Ini of the Department of Veterinary Medicine laboratory, University of Ibadan, Mr Jatto, Mr Ayanun, Mr Mashud and Mr Seyi of Soil Science and Agricultural Science laboratory respectively of the Ahmadu Bello University, Zaria during the various practical analysis for the success of this research.

\section{Conflict of interest}

Authors declared no conflict of interest.

\author{
Authors' Contributions \\ Conception: (OSM, SAK) \\ Design: (OSM, BRA, SAK) \\ Execution: (OSM, BRA, SAK) \\ Interpretation: (OSM, BRA) \\ Writing of manuscript: (OSM, BRA, SAK)
}

\section{References}

Allan, W.H., Gough, R.E., 1974, A standard haemagglutination test for Newcastle disease. A comparison of macro and micromethods. Vet. Rec. 95:120-123.

Almeida Paz, I.C.L., Bruno, L.D.G., 2006, Bone mineral density: review. Brazilian Journal of Poultry Science. 8 (2):69 -73.
Ammann, P., Bonjour, J.P., Rizzoli, R., 2000, Essential amino acid supplements increase muscle weight, bone mass and bone strength in adult osteoporotic rats J. Musculoskeletal Neuronal Interact., 1: 43 -44.

Awad, A.M. Sedeik, M.E., Abdelkariem, A.A., 2015, Isolation, molecular characterization and pathotyping of Newcastle disease viruses from field outbreaks among broiler flocks in Egypt from 2014-2015. Int. J. Curr. Res., 7: 12925-12934.

Bao, Y.M, Choct, M., Iji, P.A., Bruerton, K., 2009, Optimal dietary inclusion of organically complexed zinc for broiler chickens. Br Poult Sci. 50: 95-102. https://doi.org/10.1080/00071660802590377 PMID:19234934.

Belury, M.A., 2002, Dietary conjugated linoleic acid in health: physiological effects and mechanisms of action. Annu Rev Nutr 22:505-531.

Berndt, T.J., Schiavi, S., Kumar, R., 2005,"Phosphatonins” and the regulation of phosphorus homeostasis. Am. J. Physiol. Renal Physiol. 289;F1170-F1182.

Choi, M.J., DiMarco, N.M. 2009, The effects of dietary taurine supplementation on bone mineral density in ovariectomized rats. Adv Exp Med Biol 643:341-349.

Choi, M.J.,Seo, J.N., 2013, Effect of taurine feeding on bone mineral density and bone markers in rats in Advance experimental medical Biology. 776:51-8. doi: 10.1007/978-1-4614-6093-0_6.

Echeonwu, B.C., Ngele, M.B., Echeonwu, G.O.N., Joannis, T.M., Onovoh, E.M., Paul, G., 2008, Response of chickens to oral vaccination with Newcastle disease virus vaccine strain $\mathrm{I}_{2}$ coated on maize offal. African Journal of Biotechnology. 7 (10) 1594 - 1599.

Glogowski, J., Danforth, D.R., Ciereszko, A. 2002, Inhibition of Alkaline Phosphatase Activity of Boar Semen by Pentoxifylline, Caffeine \& Theophylline. Journal Androl. 23-6.

Hanaa, H.A., Amal, H.H., 2009, Potential Role of Arginine, Glutamine and Taurine in Ameliorating Osteoporotic Biomarkers in Ovariectomized Rats. Report and Opinion, 1(6):24-35.

Hassan, R.A., Ebeid, T.A., Abd El-Lateif, A.I., Ismail, N.B., 2011, Effect of dietary betaine supplementation on growth, carcass and immunity of New Zealand White rabbits under high ambient temperature. Livest. Sci. 135:103-109.

Hayes, K.C., Stuiman, J.A., 1981, Taurine in metabolism. Annu Rev Nutr 1:401-425

Hazarina, N.N., 2017, The impact of selenium-rich green and black tea water extracts on bone health in vitro, and in an animal model of osteoporosis. Ph.D Research Thesis. Massey University, Palmerston North, New Zealand. 1-404.

Huang, C., Yuan, J., Zhou, S., Wang, B., 2011, Effects of dietary taurine on growth performance and developments of digestive and immune organ in broilers. Chinese Journal of Animal Nutrition. 23: 854-861.

Jae-woon, S., Hae-beom, L., Nam-soo, K., Sang- youel, P., 2009, Tartrate resistant acid Phosphatase as a diagnostic for arthritis. International Journal of Molecular Medicine. (24):57-62. 
Jila, M.R., Soleiman, M.D., 2012, Quantification and comparison of bone alkaline Phosphatase with two methods in normal and Paget's specimens. Caspian Journal of Internal Medicine. 3 (3):478-483.

Johnson, R.C, Leopold, J.A, Loscalzo, J., 2006, Vascular calcification. Pathobiological mechanisms and clinical implications. Circ Res 99: 1044-1059.

Kadam, S., Prabhasankar, P., 2010, Marine foods as functional ingredients in bakery and pasta products. Food Res. Int., 43(8):19751980. http://dx.doi.org/10.1016/j.foodres.2010.06.007.

Kirk, S.J., Barbul, A., 1992, Arginine and immunity. Pp. 160-161 in Encyclopedia of Immunology, Book I, I.M. Roitt, editor; \& P.J. Delves, editor. , eds. London: Academic Press.

Kettunen, H., Peuranen, S., Tiihonen, K., 2001, Betaine aids in the osmoregulation of duodenal epithelium of broiler chicks, and affects the movement of water across the small intestinal epithelium in vitro. Comp. Biochem. Physiol. A Mol. Integr. Physiol. 129:595-603. doi: 10.1016/S1095-6433(01)00298-7.

Kirstein, B., Chambers, T.J., $\quad$ Fuller, K., 2006, Secretion of tartrateresistant acid phosphatase by osteoclasts correlates with resorptive behavior. Journal of Cellular Biochemistry, 98: 1085-1094. doi:10.1002/jcb.20835.

Klasing, K.C, Roura, E., 1991, Interaction between nutrition and immunity in chickens. Cornell Nutrition Conference, Proceedings pp, 94-101.

Kleerekoper, M., Nelson, D.A, Peterson, E L., Flynn, M.J., Pawluszka, A.S., Jacobsen, G., Wilson, P., 1994, Reference data for bone mass, calciotropic hormones, and biochemical markers of bone remodeling in older (55-75) postmenopausal white and black women. J Bone Miner Res 9:1267-1276.

Koide, M., Okahashi, N., Tanaka, R., Shibasaki, K., Yamazaki, Y., Kaneko, K., Veda, N., Ohguchi, M., Ishihara, Y., Noguchi, T., 1999, Ihibition of experimental bone resorption and osteoclast formation and survival by 2-amino ethane sulphonic acid. Arch Oral Biol 44:711-719.

Li, C., Cao, L., Zeng, Q. Liu, X., Zhang, Y., Dai, T., Hu, D., Huang, K., Wang, Y., Wang, X., 2005, Taurine may prevent diabetic rats from developing cardiomyopathy also by downregulating angiotensin II type2 receptor expression. Cardiovasc Drugs Ther 19:105-112.

Li, P., Yin, Y. L., Li, D.F., Kim, S.W., Wu, G., 2007, Amino acids and immune function. Br. J. Nutr. 98:237-252.

Lubec, B., Ya-Hua, Z., Pertti, T., Kitzmuller, E., Lubec, G., 1997, Distribution and disappearance of the ratio labled carbon derived from arginine and taurine in mouse. Life Sci 60:2378-2381.

Ma, W., Wu, L., Zhou, F., Hong, Z., Yuan, Y., Liu, Z., 2017, Cell-associated immunotherapy for hepatocellular carcinoma. Cell Physiol Biochem 41: 609-622.

Mudasir, G.W., Ashaq, H.D., 2016, Determination of enzyme activity of acid phosphatase through standard curve of Para-nitrophenol. International Journal of Science, Engineering and Technology Research. 5: 196 -202.
Njoku, V.O., Chikezie, P.C. Kaoje, A.M., 2011, Kinetic study of alkaline phosphatase extracted from rabbit liver. African Journal of Biotechnology 10 (16), 3157-3162.

Nordin, B.E.C., 1978, Diagnostic procedures in disorders of calcium metabolism. Clin Endocrinol (Oxf) 8:55-67.

Ogunbode, S.M., Iyayi, E.A., Owoade A.A., and Okanlawon, A.A., 2013, "Effect of Low Protein-Methionine-and-Lysine-Supplemented Diets on Performance, Immune Response and Carcass Characteristics of Broilers" Bulletin of Animal Health and Production in Africa. 61, 369382. ISSN 0378-9721.

Osyczka, A,M., Leboy, P. S., 2005, Bone morphogenetic protein regulation of early osteoblast genes in human marrow stromal cells is mediated by extracellular signal-regulated kinase and phosphatidylinositol 3-kinase signaling. Endocrinology, 146: 34283437. doi:10.1210/en.2005-0303.

Park, S., Kim, H., Kim, S.J., 2001, Stimulation of ERK2 by taurine with enhanced alkaline phosphatase activity and collagen synthesis in osteoblast-like UMR-106 cells. Biochem Pharmacol_62: 1107-1111.

Rao, S.V., Raju, M.V.L.N., Panda A. K., Saharia, P., Sunder, G.S., 2011, Effect of supplementing betaine on performance, carcass traits and immune responses in broiler chicken fed diets containing different concentrations of methionine. Asian-Aust. J. Anim. Sci. 24:662-669. doi: 10.5713/ajas.2011.10286.

Schaffer, S.W., Chian, J.J., Ramila, K.C., Junichi, A., 2010, Physiological roles of taurine in heart and muscle. Journal of Biomedical Science 17(Suppl 1):S2.

Schuller-Levis, G., Mehta, P. D., Rudelli, R., Sturman, J., 1990, Immunologic consequences of taurine deficiency in cats. J. Leukoc. Biol. 47, 321-331.

Sharideh, H., Zhandi, M., Zaghari, M., Akhlaghi, A., 2015, Effect of dietary zinc oxide and phytase on the plasma metabolites and enzyme activities in aged broiler breeder hens. Iran J Vet Med. 9; 263-270.

Shim, K.S., Hwang, K.T., Son, M.W., Park, G.H., 2006, Lipid metabolism and peroxidation in broiler chickens under chronic heat stress. AsianAustralasian Journal of Animal Science 19:1206-1211.

Siemowit, M., Tomasz, E.E., Malsorzata, K., Pitro, D., Agnlesma, T.W., 2018, Subsequent somatic axis and bone tissue metabolism responses to a low-zinc diet with or without phytase inclusion in broilers chickens. Journal Pone. PLOs ONE 13:(1) e0191964.https://doi.org/10.1371/64.

Skoog, D.A., Holler, F.J., Crouch. S.R., 2006, Principles of instrumental analysis. 6 th ed. Brooks Cole, Belmont, CA, USA.

Snyder, D.B., Marquardt, W.W., Mallinson, E.T., and Savage, P.K., 1984, An enzyme-linked immunosorbent asay.III. Simultaneous measurements of antibody titers to infectious bronchitis, infectious bursal disease, and New-castle disease viruses in a single serum dilution. Avian Dis. 28: 12-24.

Statistical Analysis System, 2000, SAS Version 9.1. SAS Institute Inc., Raleigh, North Carolina, U.SA. 
Termine, J.D. 1993, Bone matrix proteins and the mineralization process. In: Favus MJ (ed) Primer on the Metabolic Bone Diseases and Disorders of Mineral Metabolism. Raven Press, New York, pp 21-25.

Tsiagbe, V.K., Cook, M.E. Harper, A.E., Sunde, M.L., 1987, Enhanced immune responses in broiler chicks fed methionine-supplemented diets. Poult. Sci. 66:1147-1154.

Tucker, L.A., Nokes, N., Adams, T., 2007, "Effect of a Dietary Supplement on Hip and Spine BMD". Medicine \& Science in Sports \& Exercise 39: S230.

Wang, F.R., Dong, X.F., Tong, J.M., Zhang, X.M., Zhang, Q., Wu, Y.Y., 2009, Effects of dietary taurine supplementation on growth performance and immune status in growing Japanese quail (Coturnix coturnix japonica). Fish. Sci. 88, 1394-1398.

Wang, Q., He, G., Wang, X., Mai, K., Xu, W., Zhou, H., 2014, Dietary sulfur amino acid modulations of taurine biosynthesis in juvenile turbot (Psetta maxima). Aquaculture, 422, 141-145.
Yasutomi, C., Nakamuta, H., Fujita, T., Takenaga, T., Koida, M., 2002, Anti-osteopenic effect of taurine: possible involvement of activated MEK-ERK-Cbfa1 signaling Nippon Yakurigaku Zasshi., 120: 114-115.

Wang, Q., He, G., Wang, X., Mai, K., Xu, W., Zhou, H., 2014. Dietary sulfur amino acid modulations of taurine biosynthesis in juvenile turbot (Psetta maxima). Aquaculture, 422, 141-145.

Yasutomi, C., Nakamuta, H., Fujita, T., Takenaga, T., Koida, M., 2002. Anti-osteopenic effect of taurine: possible involvement of activated MEK-ERK-Cbfa1 signaling Nippon Yakurigaku Zasshi., 120: 114-115. 